\title{
Detection of Streptococcus mutans and Streptococcus sobrinus in Dental Plaque Samples from Brazilian Preschool Children by Polymerase Chain Reaction
}

\author{
Teresa Cristina Costa FRANCO E FRANCO ${ }^{1}$ \\ Patrícia AMOROSO ${ }^{1}$ \\ José Moacir MARIN ${ }^{2}$ \\ Fernando Antonio de ÁVILA ${ }^{3}$ \\ ${ }^{1}$ School of Dentistry, Educational Foundation of Barretos, Barretos, SP, Brazil \\ ${ }^{2}$ School of Dentistry of Ribeirão Preto, University of São Paulo, Ribeirão Preto, SP, Brazil \\ ${ }^{3}$ School of Agrarian Sciences and Veterinary Medicine, São Paulo State University, Jaboticabal, SP, Brazil
}

\begin{abstract}
The purposes of this study were to detect $S$. mutans and $S$. sobrinus by polymerase chain reaction (PCR) amplification, and to relate their presence to the incidence of dental caries in 42 Brazilian preschool children. Dental plaque samples were collected from the cervical margin of all erupted teeth of 5-6 years old children with primary dentition, using a sterile explorer. Examination of the dmft (decayed, missing, filled teeth) index, performed following the World Health Organization (WHO) caries diagnostic criteria, showed a 2.71 score. Prevalence of S. mutans and S. sobrinus was respectively, of $85.7 \%$ and $14.3 \%$; no dental plaque sample was either positive or negative for both bacterial species. Children harboring either $S$. mutans or S. sobrinus presented the same caries prevalence. PCR showed good discriminative ability for differentiation between these species, and suggested that it is a technique suitable for epidemiological studies on mutans streptococci.
\end{abstract}

Key Words: mutans streptococci, dental caries, preschool children, polymerase chain reaction.

\section{INTRODUCTION}

Dental caries, one of the most common infectious diseases in humans, is still a significant public health problem in several countries (1). Mutans streptococci (MS) (Streptococcus mutans and Streptococcus sobrinus), the most common pathogens isolated from human dental plaque, are considered the major etiologic agents of caries disease. Epidemiological studies have reported that $S$. mutans is more prevalent than $S$. sobrinus in dental plaque $(1,2)$, but have also shown that the prevalence of $S$. sobrinus is more closely associated with a high caries incidence (3).

Identification of $S$. mutans and S. sobrinus on selective media, such as Mitis-salivarius or Mitissalivarius-bacitracin agar has used colonial morphology (4). However, the differentiation between S. mutans and $S$. sobrinus is not easy, and is also a time-consuming procedure (5). Therefore, immunological (5) and biochemical (6) testing has now been performed on screened bacterial colonies. Nevertheless, a polymerase chain reaction (PCR) method for simple, rapid and reliable identification of MS species has also been developed (7).

The purposes of this study were to detect $S$. mutans and S. sobrinus by PCR amplification, and to relate their presence to the incidence of dental caries in preschool children.

Correspondence: Prof. Dr. José Moacir Marin, Departamento de Morfologia, Estomatologia e Fisiologia da Faculdade de Odontologia de Ribeirão Preto, Universidade de São Paulo, Avenida do Café, S/N Campus USP, 14040-904 Ribeirão Preto, SP, Brasil. Tel: +55-16-36024101. Fax: +55-16-3633-0999. e-mail: jmmarin@forp.usp.br 


\section{MATERIAL AND METHODS}

\section{Study Population}

Forty-two Brazilian preschool children aged 5-6 years, with primary dentition and attending two nursery schools in the city of Barretos, State of São Paulo, Brazil were enrolled in this study conducted between May and June of 2003. Approval by Local Education and Health Authorities was obtained, and consent for participation was granted by at least one of the children's parents prior to the study. A population of boys and girls was randomly select independently of gender, race or socioeconomic level. All participants followed the same meal schedule at school. Subjects underwent dental examination for caries prevalence by two well-trained pediatric dentists (P.A and T.C.F.F) who applied the World Health Organization's (WHO) caries diagnostic criteria to determine the $\mathrm{dmft}$ (decayed, missing, filed teeth) index (8), in a fully equipped dental unit. Caries per tooth surface were visually diagnosed. Children who had taken antibiotics within the previous 3 months or with systemic diseases were excluded. Inter-examiner reproducibility for $\mathrm{dmft}$ was over $90 \%$ in samples taken from 10 subjects.

\section{Plaque Sampling}

Dental examinations were performed under natural light, using a plane dental mirror and explorer. One plaque sample was collected from each subject along the cervical margin of the teeth. Each explorer was immediately placed in a tube containing sterile $\mathrm{pH} 7.0$ phosphate-buffered saline, and processed within 2-3 h after collection by vigorous shaking prior to removal. Tubes were then vortexed for $30 \mathrm{~s}$ for content homogenization. A volume of $0.1 \mathrm{~mL}$ was spread onto sucrose bacitracin agar $\left(\mathrm{SB}_{20}\right)$ modified by Azevedo et al. (9).

\section{Microbiological Processing}

After a three-day incubation period under a $\mathrm{CO}_{2}$ enriched atmosphere at $37^{\circ} \mathrm{C}$, the agar plates were inspected for growth of MS colonies, under a stereoscopic microscope. At least five colonies per child were examined to confirm the presence of $S$. mutans or S. sobrinus. Pure cultures of each isolate were identified by their capacity to ferment mannitol, sorbitol, melibiose, raffinose and inulin, arginine hydrolyses, hydrogen peroxide and catalase production (3). $S$. sobrinus was identified by fermentation of mannitol and inulin, but not of melibiose or raffinose, and lack of ability to release ammonia from arginine and hydrogen peroxidase production.

\section{Chromosomal DNA Extraction}

A previously described, small scale chromosomal DNA extraction procedure was used (10). Briefly, cells were washed in $0.1 \mathrm{M}$ Tris buffer, lysed with lysozyme $+10 \%$ SDS and extracted with phenolchloroform. DNA was precipitated with sodium acetate and ethanol, and its concentration in the dental plaque samples was calculated by measuring A260. Quality was estimated from A260/A280 ratio (11). DNA yield was measured in a RNA/DNA calculator (Amersham Pharmacia Biotech, Uppsala, Sweden).

\section{Oligonucleotide Primers and PCR Procedure}

Oligonucleotide primers GTFB- F5'ACTACACTTTCGGGTGGCTTGGand GTFB- R5'CAGTATAAGCGCCAGTTTCATC were designated to amplify a $517 \mathrm{bp}$-DNA fragment of the $g t f \mathrm{~B}$ sequence of $S$. mutans, and primers GTFI- F5'GATAACTACCTGACAGCTGACT and GTFI- R5'AAGCTGCCTTAAGGTAATCACT were designated to amplify a $712 \mathrm{bp}$-DNA fragment of the $g t f$ I sequence of S. sobrinus. The PCR mixture was the same used by Oho et al (7). The PCR conditions were denaturation at $95^{\circ} \mathrm{C}$ for $30 \mathrm{~s}$, followed by annealing at $59^{\circ} \mathrm{C}$ for $30 \mathrm{~s}$, and extension at $72^{\circ} \mathrm{C}$ for $1 \mathrm{~min}$. This amplification was repeated for 30 cycles. The final cycle was run at $72^{\circ} \mathrm{C}$ for $5 \mathrm{~min}$. Along with these samples, positive and negative controls were run for each experiment, using purified genomic DNA from $S$. mutans (CCT 1910) and S. sobrinus (ATCC 33478) respectively, as positive controls, and distilled water as negative controls. PCR products were subjected to electrophoresis on $1.5 \%$ agarose gel and stained with ethidium bromide.

\section{RESULTS}

Male and female children had almost the same level of caries prevalence (respectively, $65.0 \%$ and 
45.0\%). Dmft score was 2.71. The colonies of $S$. mutans strains formed multiberry-shaped colonies growing deep into the agar, while the very hard colonies of $S$. sobrinus were usually surround by extracellular polysaccharides. Although there was not a $100 \%$ agreement on species identification by biochemical tests and PCR, as shown on Table 1, the level of agreement obtained was quite satisfactory.

With the primers used, $S$. mutans and $S$. sobrinus produced single DNA fragments of 517 and $712 \mathrm{bp}$, respectively (7). Figure 1 shows examples of $S$. mutans and $S$. sobrinus detection in different plaque samples.

Table 1. Mutans streptococci identification using biochemical tests or PCR.

\begin{tabular}{lccccc}
\hline Species & \multicolumn{2}{c}{$\begin{array}{c}\text { Caries-active } \\
\text { subjects }(\mathrm{n}=23)\end{array}$} & & \multicolumn{2}{c}{$\begin{array}{c}\text { Caries-free } \\
\text { subjects }(\mathrm{n}=19)\end{array}$} \\
\cline { 2 - 3 } \cline { 5 - 6 } & $\begin{array}{c}\text { Biochemical } \\
\text { test }\end{array}$ & PCR & & $\begin{array}{c}\text { Biochemical } \\
\text { test }\end{array}$ & PCR \\
\hline S. mutans & 18 & 19 & & 17 & 17 \\
S. sobrinus & 5 & 4 & & 2 & 2 \\
Total & 23 & 23 & & 19 & 19 \\
\hline
\end{tabular}

$\mathrm{PCR}=$ Polymerase chain reaction.

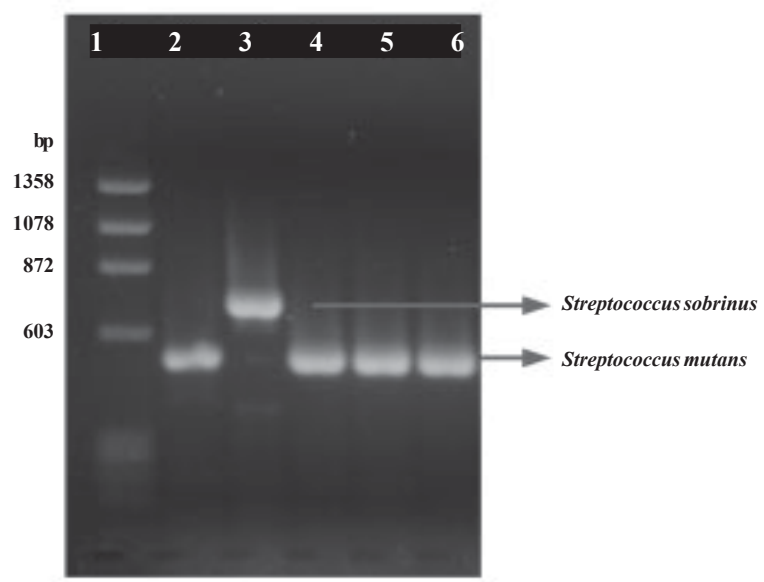

Figure 1. Detection of $S$. mutans and S. sobrinus in dental plaque samples by PCR amplification. Lane 1. DNA marker, $\Phi$ X174 phage Hae III digest (Pharmacia); lanes 2 and 3 are control chromosomal DNA from $S$. mutans (CCT 1910) and $S$. sobrinus (ATCC 33478), respectively; lanes 4, 5, 6 show the PCR product of plaque samples from different children (S. mutans).
Table 2 presents data on the distribution by gender in samples of both species, determined by PCR. S. mutans and S. sobrinus were identified, respectively, in 85.7 and $14.3 \%$ of the subjects. The proportion of males positive for $S$. sobrinus was significantly higher than that of females $(\mathrm{p}<0.01)$.

No sample presented both species or none of them. Table 3 shows the relationship between infection by both MS species and caries prevalence among the 23 caries-active and 19 caries-free subjects. There was no significant difference in caries prevalence according to infection, by either of the species.

Table 2. Prevalence of $S$. mutans and S. sobrinus according to subject gender.

\begin{tabular}{|c|c|c|}
\hline \multirow[t]{2}{*}{ Species } & Males $(n=20)$ & Females $(n=22)$ \\
\hline & Number (\%) & Number (\%) \\
\hline Positive for $S$. mutans & $16(80)$ & $20(91)$ \\
\hline Positive for $S$. sobrinus & $4(20)$ & $2(9)$ \\
\hline $\begin{array}{l}\text { Positive for } S . \text { mutans } \\
+S \text {. sobrinus }\end{array}$ & $0(0)$ & $0(0)$ \\
\hline $\begin{array}{l}\text { Negative for } S \text {. mutans } \\
+S . \text { sobrinus }\end{array}$ & $0(0)$ & $0(0)$ \\
\hline
\end{tabular}

Table 3. Comparison between subjects according to infection by S. mutans and/or S. sobrinus and caries prevalence.

\begin{tabular}{lcccc}
\hline Species & $\begin{array}{c}\text { Caries-active } \\
\text { subjects } \\
\mathrm{n}(\% \text { of total) }\end{array}$ & $\begin{array}{c}\text { Caries-free } \\
\text { subjects }\end{array}$ & $\begin{array}{c}\text { Total } \\
\text { Caries } \\
\text { prevalence } \\
(\%)\end{array}$ \\
\hline $\begin{array}{l}\text { Positive for } \\
\text { S. mutans }\end{array}$ & $19(82.6)$ & 17 & 36 & 52.7 \\
$\begin{array}{l}\text { Positive for } \\
\text { S. sobrinus }\end{array}$ & $4(17.4)$ & 2 & 6 & 66.6 \\
$\begin{array}{l}\text { Positive for } \\
\text { S. mutans/ }\end{array}$ & 0 & 0 & 0 & 0 \\
$\begin{array}{l}\text { S. sobrinus } \\
\text { Negative for }\end{array}$ & & & & \\
$\begin{array}{l}\text { S.mutans/ } \\
\text { S. sobrinus }\end{array}$ & 0 & 0 & 0 & 0 \\
\hline
\end{tabular}




\section{DISCUSSION}

Dental caries is an infectious disease in which members of the MS group have been implicated as major etiological agents. Most humans harbor MS, but not all humans manifest caries $(1,2)$. S. mutans and $S$. sobrinus are the most commonly found MS species in humans and the correct identification and differentiation among them is an important step to understand the early phases of colonization of the oral cavity.

In the present study, biochemical tests allowed the identification and differentiation of both species in caries-free and caries-active children, in good agreement with PCR results. However, as the conventional procedures used to detect and identify cariogenic bacteria from the dental plaque demand a long time (1 week) to be completed, the less time consuming PCR method ( 1 day) that produced the same results acquires greater usefulness.

The dmft score found was 2.71, a value close to 2.27 reported by other authors (12) for Brazilian children. Rates here reported for caries-free children $(45.0 \%)$ agree with other reports $(12,13)$. The prevalence of $S$. mutans and S. sobrinus in children aged 5-6 years, found in this study, were $85.7 \%$ and $14.3 \%$ respectively, in agreement with the results of Amoroso et al. (14) and Klein et al. (15). However, the outcomes of the present study were quite different from those of Okada et al. (16), who reported $72.8 \%$ and $61.1 \%$ for $S$. mutans and S. sobrinus in 3-5 years old Japanese preschool children. In another study, Okada et al. (17) found prevalences of $61.7 \%$ and $56.6 \%$ for $S$. mutans and S. sobrinus, respectively, in Japanese children. In both studies $(16,17)$ the authors reinforced the statement that children who harbor both bacteria together have a significantly higher caries incidence and incremented increase, compared to those with S. mutans alone. In the present study, it was no detected the presence of both species together in any dental plaque sample from Brazilian children. Differences between MS acquisitions in infants could reflect true differences of diet, which, in turn, could reflect differences in the biofilm formed on the dental tissue.

S. sobrinus has a high cariogenic potential in experimental animals (18). In the present study, there were several cases of caries-free children who had $S$. mutans or S. sobrinus alone ( $\mathrm{n}=19$, Table 3$)$. In a recent study (17), 13 out of 77 (16.9\%) children were shown to be caries-free. Even though, 7 (53.8\%) of them presented either S. mutans or S. sobrinus alone, in agreement with the present results.

Several studies have reported that children harboring both $S$. mutans and $S$. sobrinus had a significantly higher caries incidence than those with either S. mutans or $S$. sobrinus alone $(16,17,19)$. Recently, a hypothesis stating that mixed colonization by both $S$. mutans and $S$. sobrinus is an important factor for the development of caries has been reported (20). However, the results of the present study disagree with this statement, as they show that subjects infected with either $S$. mutans or $S$. sobrinus had the same caries prevalence (Table 3 ).

In conclusion, this study demonstrated that PCR is a reliable method for the detection of S. mutans and $S$. sobrinus in epidemiological studies. It was also observed that children presenting either S. mutans or S. sobrinus have potential to develop caries.

\section{RESUMO}

A presença de Streptococcus mutans e S. sobrinus, detectadas através da técnica da reação em cadeia da polimerase (PCR) foi comparada com a incidência de cárie dental em 42 crianças préescolares brasileiras. As amostras da placa dental foram obtidas utilizando-se um explorador estéril, o qual foi passado na margem cervical de todos os dentes erupcionados nas crianças de 5-6 anos de idade, as quais possuíam a dentição primária. Foi realizado um exame dental para a avaliação do índice ceod (índice de dentes decíduos cariados, extraídos por cárie ou obturados) de acordo com os critérios de diagnóstico de cárie preconizados pela Organização Mundial de Saúde(OMS). O índice ceod foi de 2,71. A presença de $S$. mutans e $S$. sobrinus foi detectada em $85,7 \%$ e $14,3 \%$ das crianças analisadas respectivamente, nenhuma amostra da placa dental foi positiva ou negativa para a presença das duas bactérias ao mesmo tempo. As crianças que apresentavam $S$. mutans ou $S$. sobrinus isoladamente apresentaram o mesmo índice de cárie. A técnica de PCR apresentou um grande poder discriminatório entre as duas espécies o que sugere que ela é adequada para estudos epidemiológicos no grupo mutans.

\section{REFERENCES}

1. Ramos-Gomez FJ, Weintraub JA, Gansky AS, Hoover CI, Featherstone JD. Bacterial, behavioral, and environmental factors associated with early childhood caries. J Clin Pediatr Dent 2002;26:165-173.

2. Loesche WI. Role of Streptococcus mutans in human dental decay. Microbiol Rev 1986;50:353-380.

3. Hirose H, Hirose K, Isogai E, Miura H, Ueda I. Close association between Streptococcus sobrinus in the saliva of young children and smooth-surface caries increment. Caries Res 1993;27:292-297.

4. Svanberg M, Krasse B. Comparative recovery of mutans streptococci on two selective media. Caries Res 1990;24:36- 
38

5. de Soet JJ, van Dalen PJ, Pavicic MJAMP, de Graaff J. Enumeration of mutans streptococci in clinical samples by using monoclonal antibodies. J Clin Microbiol 1990;28:24672472 .

6. Beighton D, Russel RRB, Whiley RA. A simple biochemical scheme for the differentiation of Streptococcus mutans and Streptococcus sobrinus. Caries Res 1991;25:174-178.

7. Oho T, Yamashita Y, Shimazaki Y, Kushiyama M, Koga T. Simple and rapid detection of Streptococcus mutans and Streptococcus sobrinus in human saliva by polymerase chain reaction. Oral Microbiol Immunol 2000;15:258-262.

8. World Health Organization. Individual tooth status and treatment need. In: Oral Health Surveys: Basic Methods, 3rd ed. Geneva, Switzerland. World Health Organization, 1987:3439.

9. Azevedo RVP, Nelson Filho P, Assed S, Ito IY. Streptococci of the mutans group: isolation, identification, and prevalence of species in the saliva of mother-child pairs. Rev Odontol Univ São Paulo (currently Braz Oral Res) 1998;12:47-50.

10. Li Y, Caufield PW. The fidelity of initial acquisition of mutans streptococci by infants from their mothers. J Dent Res 1995;74:681-685.

11. Sambrook J, Fritsch EF, Maniatis T. Molecular Cloning: A laboratory manual. 2th ed. Cold Spring Harbor Laboratory Press; 1989.

12. Saliba NA. Prevalence of dental caries in 3 to 6 years-old from Araçatuba, SP, Brazil, 1996. Rev Odontol UNESP 1996;27:207-213.
13. Lira CC, Moraes ES, Thomaz EBAF, Ely MR, Valença AMG. Experience and distribution of dental caries in children aged 2 to 5 years. Rev Odontol UNESP 2001;30:55-66.

14. Amoroso P, Franco e Franco TCC, Marin JM, Ávila FA. Comparative study on PCR and fenotypic on the detection of Streptococcus mutans and Streptococcus sobrinus and tranmission study. Cienc Odont Bras 2004;7:30-40.

15. Klein MI, Flório FM, Pereira AC, Hofling JF, Gonçalves RB. Longitudinal study of transmission, diversity, and stability of Streptococcus mutans and Streptococcus sobrinus genotypes in Brazilian nursery children. J Clin Microbiol 2004;42:46204626.

16. Okada M, Soda Y, Hayashi F, Doi T, Suzuki J, Miura K, Kozai K. PCR detection of Streptococcus mutans and S. Sobrinus in dental plaque samples from Japanese preschool children. J Med Microbiol 2002;51:443-447.

17. Okada M, Soda Y, Hayashi F, Doi T, Suzuki J, Miura K, Kozai $\mathrm{K}$. Longitudinal study of dental caries incidence associated with Streptococcus mutans and Streptococcus sobrinus in preschool children. J Med Microbiol 2005;54:661-665.

18. de Soet JJ, van Loveren C, Lammens AJ. Differences in cariogenicity between fresh isolates of Streptococcus sobrinus and Streptococcus mutans. Caries Res 1991;25:116-122.

19. Lindquist B, Emilson CG. Dental location of Streptococcus mutans and Streptococcus sobrinus in human harboring both species. Caries Res 1991;25:146-152.

20. Seki M, Yamashita Y, Shibata Y, Torigoe H, Tsuda H, Maeno M. Effect of mixed mutans streptococci colonization on caries development. Oral Microbiol Immunol 2006;21:4752 